\title{
Medical research, the media and open access
}

M ousing through email peddlers of pornography, Viagra and cheap holidays we understand, again, McLuhan's notion that the "medium is the message" because "it shapes and controls the scale and form of human association and action." But must we accept whatever technologic advance in communications that comes along? Writing almost a decade before Tim Berners-Lee invented the World Wide Web, Raymond Williams noted that " $[\mathrm{t}]$ he moment of any new technology is a moment of choice." He speculated that new media were likely to "be dominated by financial institutions, mail-order marketers, travel agencies and general advertisers." Alternatively, however, they could be "wholly developed within public ownership." The uses of technology, Williams argued, are not "inevitable," but involve choice.

In this issue, Tania Bubela and Timothy Caulfield (page 1399) consider the interface between two media by examining the transfer of genetic research findings from scientific journals to broadsheet newspapers. Are scientific findings hyped or distorted? In an accompanying commentary (page 1415) Celeste Condit provides an overview of the complex facets of science reporting to the public. "Does the message get twisted?" she asks, and considers the responsibilities of researchers themselves in this regard.

But while medical journals still intersect in interesting ways with traditional news media, their self-directed ventures into electronic formats also have an impact on content and its reception. Online publication brings a different readership, and a wider authorship. Our online survey indicates that over $40 \%$ of the estimated annual total of 1.2 million visitors (in Webspeak, "distinct hosts") to eCMAf do not have access to the print journal, and that fewer than a third are Canadian (www.cmaj.ca/pdfs/eCMAJsurvey2003.pdf).

Although the costs of providing versions of journals like eCMAJ are, on a per-user basis, very small, some journals believe that online access will cause their paying subscriber base to shrink, especially if online access is open and free. ${ }^{3}$ Researchers who joined the Public Library of Science (www.plos.org) believe that research is a public good, one that should be "open" (and free) to all comers. Funding agencies $^{4}$ have begun to require publication in open-access journals as a condition of funding, and some politicians are moving to legislate open access publication of research supported by government funding agencies.

Does any of this really matter? Our reading of the scant evidence suggests that providing online access does im- prove (by a factor of about 4.5) subsequent use of published findings by other researchers. ${ }^{6}$ There is no doubt that readership is vastly increased, both in number and in geographic dispersion, by open access. Our last survey brought readers from 115 countries. And, the readers are in only a small proportion $(41 \%)$ physicians or researchers.

Private domain, or public good? Open or restricted access? Some publishers are trying to have it both ways, hoisting the banner (or logo) of "open access" (for a definition, see www.earlham.edu/ peters/fos/bethesda.htm) but with restrictions: open, but only after a delay, during which access is limited to paying subscribers; open immediately, but only for certain articles picked by the editors; open, but only to some sections of the journal. Others congratulate themselves on their participation in HINARI, the WHO program to provide all journal content free to users from countries with a per capita GNP below US\$1000: not much of a sacrifice, since there are few potential paying subscribers in these countries. There is still much work to do before we achieve truly global, and fully open, access to scientific information.

We are inclined toward the notion that science is a public good. And, fortunately, at least for the moment, we believe we can maintain our policy, ${ }^{8}$ announced in 1999, of making $e C M A 7$ available free without barriers. This is not only a socially responsible policy, but a strategic one. The Internet has given us greater visibility, permitting us to form electronic relationships with new readers, authors and contributors, all of whom have strengthened the publication. We plan to continue under the banner of "Free Access" both to users and contributors. - CMA7

\section{References}

1. McLuhan. Understanding media: the extensions of man. Toronto: McGraw-Hill; 1964.

2. Williams R. Towards 2000. London: Chatto \& Windus; 1983.

3. Held MJ. Proposed legislation supports an untested publishing model. 7 Cell Biology 2003;162:170-1.

4. Wellcome Trust. Scientific publishing: a position statement by the Wellcome Trust in support of open access publishing. Available: www.wellcome.ac.uk /en/1/awtvispolpub.html (accessed 2004 Apr 7).

5. US House of Representatives. Public Access to Science Act. 108th Congress 1st Session H. R. 2613. To amend title 17, United States Code, to exclude from copyright protection works resulting from scientific research substantially funded by the Federal Government.

6. Lawrence S. Online or invisible? Nature 2001;411(6837):521. Available: http://external.nj.nec.com/ lawrence/papers/online-nature01/ (accessed 2004 Apr 7).

7. DC Principles Coalition. Washington DC principles for free access to science: a statement from not-for-profit publishers. Mar 2004. Available: www.dcprinciples.org/statement.htm (accessed 2004 Apr 7).

8. Scientific publishing picks up speed [editorial]. CMA7 2003;168(13):1637. 